THE INTERNATIONAL

REVIEW OF RESEARCH IN

OPEN AND DISTANCE LEARNING

\title{
Science Teacher Training Programme in Rural Schools: An ODL Lesson from Zimbabwe
}
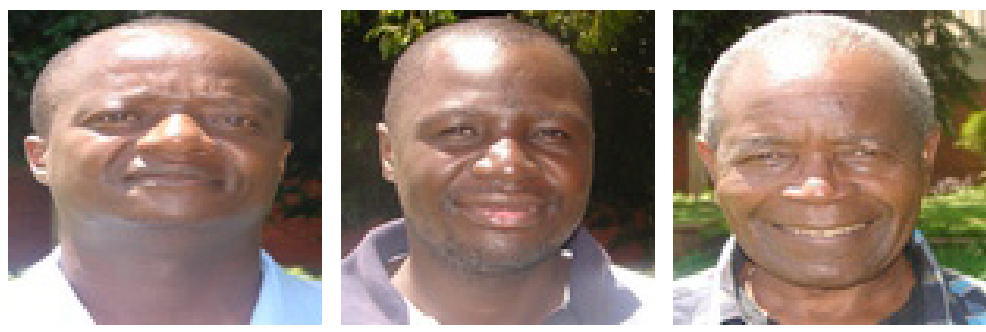

Misheck Mhishi, Crispen Erinos Bhukuvhani, and Abel Farikai Sana

Bindura University of Science Education, Zimbabwe

\section{Abstract}

This case study looked at 76 randomly selected preservice science teachers from Mbire and Guruve districts who were learning at the Mushumbi Centre in Zimbabwe and assessed their motivations for enrolling under the Bindura University of Science Education (BUSE)'s Virtual and Open Distance Learning (VODL) programme. It also looked at the challenges they faced, their views on how instruction under the programme can be improved, and their deployment preferences after graduation. The districts are located in the remote Zambezi Valley, which is characterized by poor infrastructure, pests and diseases, frequent attacks by wild animals on people, domestic animals, and crops, harsh climatic conditions, and seasonal floods, which make it very difficult to attract and retain qualified teachers. Through targeted recruitment, BUSE's VODL programme sought to train relief teachers already serving in the area in the hope that personal history and family connections would entice them to continue teaching in these areas after attaining their teacher certification. Data was collected using a questionnaire with closed and open-ended questions. Results obtained indicate that despite a lack of funding, a shortage of reading materials, and the nonavailability of e-learning facilities, the students were motivated to join the programme for personal and professional motives and that the students, the majority of whom had taught for two or more years in the districts, would prefer deployments in the area after graduation. The study therefore recommends that deliberate efforts be directed toward the targeted recruitment of school leavers and relief teachers from disadvantaged rural areas who possess the requisite minimum entry qualifications to train as science teachers in order to improve teacher retention in remote areas. Further research into the intrinsic problems in BUSE's VODL programme and a close scrutiny of its course development techniques are also encouraged in order to overcome some of the problems encountered by both the students and the institution. 
Keywords: Distance learning; skills retention; rural schools; targeted recruitment

\section{Background to the Study}

Since regaining independence in 1980, Zimbabwe has made substantial progress toward widening access to primary and secondary education. This has necessitated a proportional increase in the number of trained teachers. The number of teachers' colleges increased significantly during the first decade so as to supply a sufficient number of trained teachers to service the expanding system. Innovative approaches to the training of primary school teachers were adopted to augment teacher supplies from the conventional colleges. Preservice teacher training in four of the ten colleges that trained primary teachers combined short residential training (a duration of about one year) with extended teaching practice in the schools (a total duration of about three years). This approach to teacher education was called the Zimbabwe Integrated Teacher Education Course (ZINTEC) (UNESCO, 2000).

However, in the decade from 2000-2010, Zimbabwean schools have been hard hit by shortages of trained science teachers as a result of low enrollments at teacher training colleges, brain drain, and economic challenges faced by the country (Chetsanga, 2000). For example, the current staffing situation in Mashonaland Central Province, which has the lowest provincial literacy rate of $75 \%$ compared to the national rate of $96 \%$ (UNESCO, 2000), is critical in the sense that the majority of science teachers in the rural areas are relief teachers. Reportedly, over $80 \%$ of the science teachers in the Mbire and Muzarabani districts were either unqualified or required upgrading of their qualifications (interview with Mashonaland Central Provincial Education Director, 28 April, 2010). The current conventional science teacher education delivery system cannot totally cater to the local demand for science educators.

It was the demand for large numbers of science teachers within a short timeframe in Zimbabwe's rural schools that gave birth to the BUSE VODL programme. The programme is an in-service one that recruits untrained teachers who are working as science teachers. The programme is a concurrent model where academic subjects and professional studies are jointly offered. This is in contrast to the consecutive model where professional studies follow on a previous programme of academic studies ((Robinson \& Latchem, 2003). Currently, four centres in Mashonaland Central Province are operational: Mbire and Guruve districts at Mushumbi High School, Muzarabani district at St. Albert's Mission, Mount Darwin district at Chindunduma High 1, and Bindura-Mazoe districts at Bradley High School. The programme has since gone national with the opening of two learning centres in the Matebeleland provinces and another one in Mutare. Learning centres were established at secondary schools in the remote districts of the provinces. These centres serve as resource centres that ideally should have access to the Internet and offer minilibrary facilities. However, in reality, some of these centres have very limited resources. Print technology with face-to-face meetings and written feedback on students' assignments is predominantly used. Print was chosen because it is accessible, affordable, and familiar, and because it provides a permanent resource that student teachers can use (UNESCO, 2001). 
It was envisaged that the VODL programme would provide an opportunity for the university to train science educators in the comfort of their workplaces and homes during school holidays at an affordable cost. A major handicap to teacher supply is that once qualified, teachers may shun working in rural areas (Hedges, 2000; Akyeampong \& Lewin, 2002). The BUSE strategy was to embark on targeted recruitment, that is, to seek to recruit student teachers from the relief teachers already serving in the district in the hope that personal history and family connections would entice them to continue teaching in these areas after their graduation as qualified teachers.

There is some evidence from research and from the UK Open University's PGCE programme that twice as many teachers trained through ODL stay in the profession longer than those trained in conventional courses. This means that while intakes in ODL courses may be relatively smaller in some countries, its impact may be larger in the longer term in light of its contribution to teacher retention rates (Walker, 2001).

The interest that the relief teachers in the Mbire and Guruve districts have shown toward the BUSE VODL programme has triggered the present investigation into their motives to train as science teachers. Research has shown that knowledge about student characteristics and motivators helps with understanding who is likely to participate in and to complete a course in distance education. Similarly, such knowledge is vital since the motivators of adult distance students are often different from those of conventional students; therefore, knowing students' personal characteristics and motivations is important in planning and formulating policies for ODL programmes (Galusha, 1997).

Apart from that, a desire to document problems that may be faced by VODL students and to learn their views on how these difficulties could be curtailed also prompted this study. A need to predict the possible deployment trends of the same student teachers after graduation, that is, whether they would remain in the district, move into other, better perceived schools, or urban areas, was another push behind this study. Conclusions will be drawn from the responses of a questionnaire applied to 76 randomly sampled student teachers under the BUSE VODL programme in April-May of the 2011 teaching block session at Mushumbi High School in Mbire, Mashonaland Central Province of Zimbabwe. With these preoccupations in mind, the study sought to answer the following research questions:

1. What were the preservice teachers' motivations for training as science teachers under the VODL programme?

2. What problems did the student teachers encounter during their studies under the VODL science teacher training programme?

3. How best could BUSE conduct its ODL programme in order to improve teaching and learning?

4. What are the deployment preferences of preservice teachers in Mbire and Guruve districts after graduating as qualified teachers? 


\section{Theoretical Framework}

According to a 2001 UNESCO report, the world needs more well-trained educators in order to meet the target of Education for All by 2015. This came after the realisation that too many practicing teachers are still untrained and unqualified. Such urgent need for large numbers of additional teachers has focussed increased attention on the potential of distance education. Distance education can be a viable option for preservice, in-service, and continuing professional development for teachers (Robinson \& Latchem, 2003). It is accepted the world over that the teaching profession can be strengthened through the use of distance education or open and distance learning (UNESCO, 2001).

This realisation culminated in the launch of the BUSE VODL programme as an institutionally borne strategy to satisfy the training needs of prospective science educators who are already employed or wish to be employed by the Zimbabwean Ministry of Education, Sport, Arts, and Culture. The programme runs on a special kind of delivery strategy that merges Block Release and ODL methodologies. Lectures are conducted at the learning centres during one month long school holidays, while examinations are taken at the university's main campus in Bindura at the end of each semester. Two school holidays and the period in between constitute a VODL semester.

The success of ODL programmes hinges on individual, national, and institutional structures, as well as on students' willingness to undertake courses under this mode of education (UNESCO, 2001). This is so because the motives behind students' wishes to obtain a higher qualification may be diverse. For some, it may be for personal actualisation, and for others it may be for professional fulfilment. According to Azam (2001) and Hedges (2002), a teaching qualification may mean job security for some students from poor backgrounds, a chance for social mobility for others, or a passport to move to a "better" location, such as an urban area, or even to seek "greener pastures" outside the country.

However, undertaking courses under open distance learning programmes may have its own challenges. In many developing countries, the nonavailability of a reliable telecommunication network in remote districts, coupled with the cost of providing such technologies, as well as the low levels of penetration of the personal computer, have meant that e-learning, an inseparable component of distance education, cannot be easily implemented (Chikuya, 2007). The absence of e-learning facilities in rural areas has tended to worsen the shortages of reading materials faced by students.

The flexibility inherent in ODL and the fact that it can be undertaken concurrently with a full-time job makes it very convenient for student teachers as it allows them to study at an "affordable" cost and in the comfort of their homes and workplaces during school holidays. Furthermore, ODL courses and qualifications have the same value as those offered under conventional courses (Daniel, 2001). To this end, ODL has been adopted in different contexts in initial teacher training and in teacher skills upgrading programmes in such places as the National Teachers' Institute (Nigeria) and the China Television Teachers' College (China), as well as in India, Chile, the United Kingdom, Brazil, and South Africa (Pot- 
ter, 2001; Cerda, Leon, \& Ropoll, 2001; Mehrotra, 2001; Ederinoye, 2001; Walker, 2001; Oliveira, 2001; Zhang \& Jian, 2001; Robinson, 1997; Robinson \& Latchem, 2003).

The supply of teachers is adversely affected in many countries where retention rates are low for newly trained teachers or where significant numbers of teachers are being lost through HIV-AIDS, and in rural areas that have difficulty recruiting and retaining teachers (Daniel, 2001). Many countries report that teachers express a strong preference for urban postings. For example, in Ghana, over $80 \%$ of teachers said they preferred to teach in urban schools (Akyeampong \& Lewin, 2002). There are a number of rational reasons why teachers may prefer urban postings. One of the concerns about working in rural areas is that the quality of life may not be as good, and teachers have expressed concerns about the quality of accommodations (Akyeampong \& Stephens, 2002), classroom facilities, school resources, and access to leisure activities (Towse, Kent, Osaki, \& Kirua, 2002). Health concerns are also a major issue. According to Akyeampong and Stephens (2002), teachers may perceive that living in rural areas involves a greater risk of diseases and pests. Similarly, in the districts of Mbire and Guruve in Mashonaland Central under this study, poor infrastructure, very high climatic temperatures and low rainfall, perennial flooding, frequent attacks by wild animals on people, domestic animals, and crops, the high risk of contracting malaria and cholera, and the infestation of the tsetse fly are real, worrisome problems.

Teachers may also see rural areas as offering fewer opportunities for professional growth, while urban areas offer easier access to further educational development (Hedges, 2000). Teachers in rural areas may even find it more difficult to get their salaries on time, sometimes to the extent of having to put up with various frustrations such as political mistrust, corruption by officials, and the late submission of relevant papers to higher offices, resulting in late payments (Mulkeen, 2005).

In Zimbabwe, nearly all teachers are civil servants. Their deployment and distribution to meet the demand in the various regions, districts, and types of schools (regardless of ownership) is the responsibility of the government. Such a centralised deployment system has the advantage of distance from local pressures and can be more easily made fair and transparent. However, all these characteristics are dependent on the quality of information the government receives from the schools. According to Gottelmann-Duret and Hogan (1998) and Rust and Dalin (1990), centralised deployment is prone to congested decision-making and lacks attention to the individual needs of the teachers. Another weakness is that, practically, it is undermined by an inability to implement rational deployment (Hedges, 2000), that is, once the teachers are deployed, they may request transfers to more desirable areas. Although long delays may be experienced before teachers can transfer, many eventually get to move to where they want. For female teachers, transfers may be requested on the basis of marriage. In Malawi, there were some reports of women faking marriages in order to get transfers (Mulkeen, 2005). Teacher illness is another major justification for movement, and some teachers have circumvented the Ministry's posting policy by claiming fictitious health problems. All of this has resulted in disparities in teacher supply between rural areas and urban areas with more than 95\% of teachers in Zimbabwe teaching in urban schools as qualified teachers, while rural schools recorded the least number of qualified teachers 
(UNESCO, 2000).

As a result, rural schools have been poorly staffed or have longer delays in filling posts. Even if posts are filled, the rural schools may have fewer qualified teachers than their urban counterparts. Sometimes rural schools have less experienced teachers as the more experienced teachers find ways to move to urban schools or to the more desired schools of the district (Mulkeen, 2005). Teachers in rural schools may teach less than their counterparts in urban areas as any trip away from the area to visit a doctor, to collect pay, to engage in in-service training, or to visit family may involve long journeys and losses in man-hours. In addition, where teachers walk long distances to school, they may arrive at their workstations late and leave early. Furthermore, transport difficulties due to poor roads often make supervision visits from inspectors less frequent in many schools of the Mbire and Guruve districts, especially those in isolated parts where access is by four-wheel drive vehicles, which the Ministry of Education, Sports, Arts, and Culture cannot afford. Because the area is in the northern part of the country in the Zambezi Valley, the situation is exacerbated by seasonal floods. Even when teachers are teaching in remote districts, the quality of their work may be lower. This is partly because rural teachers often have less access to support services than their urban counterparts and fewer opportunities to attend in-service courses (Mulkeen, 2005).

The problem of teacher shortages in rural areas is often regarded as a problem of teacher numbers. However, the present pattern of high numbers of teachers in urban areas and severe shortages in the rural areas is strong evidence that the problem will not be solved simply by providing more teachers (Mulkeen, 2005; Daniel, 2001). Craig, Kraft, and du Plessis (1998) suggest that one possible solution to the shortage of qualified teachers and their retention in rural areas is to engage teachers who are "indigenous" to those rural places or to train relief teachers already serving in those areas through ODL. The presumption is that those individuals will have family roots in these areas and/or some economic interest (e.g., agricultural activity such as cotton growing in the Zambezi Valley), and so they may be more willing to train and remain in these rural settings. To justify this approach, it is believed that if teachers become established within their own community or home district, they may gain extra benefits from the proximity of relatives, which may help to ensure longterm stability. Working close to one's extended family may provide some level of moral as well as financial support and subsidy (Black, Esanu, Mugambe, Namwadda, \& Walugembe, 1993). Moreover, research studies in many countries have shown that twice as many teachers trained through ODL stay in the profession longer than those trained in conventional courses (Walker, 2001; UNESCO, 2001).

It should, however, be noted that the assumption that teachers recruited from a certain rural area would want to return to their own communities has been challenged by a number of researchers as educated members of a disadvantaged group may view their education as a means of social mobility and may have no desire to remain in the community once they are qualified (Azam, 2001; Rust \& Dalin, 1990). It is therefore presumed that the results from this research will offer insights into the possible deployment inclinations of the preservice teachers in the Mbire and Guruve districts. 


\section{Methodology}

The present research is a case study in which 76 preservice science teachers (42 males and 34 females) under the BUSE VODL teacher education programme at Mushumbi Centre (Mbire and Guruve districts) in Zimbabwe participated. These were randomly selected from a total population of 141 student teachers. The present sample constitutes $53.9 \%$ of the total population, and in coming up with the gender ratios, the researchers were guided by the programme's 1: 2.1 female to male ratio. However, a lower ratio of 1:1.2 was achieved due to the nonreturn of some questionnaires whose overall return rate stood at $66.1 \%$ despite repeated efforts to recover a larger number.

The results discussed in this paper come from a questionnaire that included a combination of open-ended and closed questions. The questionnaire items underwent pilot testing on BUSE's conventional students. The data from the pilot test were then analysed by three experienced lecturers in order to determine the efficacy of the next step of the research. The closed questions were processed through tables of frequencies and cross-tabulations obtained by using SPSS Version 17. Open-ended ones were analysed qualitatively. Qualitative analyses of statements and comments were preferred because they allow students' views on the various aspects of their learning under the VODL programme to be assessed (Cohen\& Manion, 1994; Patton, 2002).

Answers to the research questions show students' motivations for training as science teachers under the BUSE VODL programme (question 4); the problems they faced as VODL students (question 5); how, in their view, these problems may be solved (questions 6 and 7); and their willingness to undertake further professional development studies under VODL programmes (question 9). Their deployment preferences after graduation were captured by analysing the answers to question 8 of the questionnaire.

\section{Results and Discussion}

A description and an interpretation of each of the research questions are presented here.

\section{The Student Teachers' Motivations}

The majority of the participants (92.1\%) were motivated to attend the BUSE VODL teacher education programme for professional development reasons. They wanted to acquire a professional qualification to improve their teaching of science subjects in secondary schools. The following statement divulges one preservice teacher's motivations for training under the VODL programme: "to obtain a diploma in sciences so that I will be a qualified teacher with better knowledge and teaching knowledge [sic]."

Such sentiments reveal the personal and professional motivations that impel students to enroll under the BUSE VODL teacher education programme. Student motivation has a powerful effect on attrition and completion rates of ODL programmes, regardless of the challenges that may be encountered during studies (Galusha, 1997; Walker, 2001). The need to obtain a diploma in education in order to improve on the teaching and learning of 
science in schools was the major motivation for the participants. The acquisition of a higher educational qualification is both a personal and a professional motivation because it equips the students with new knowledge and confidence in science teaching, as well as a sense of self-actualisation and achievement.

A significant number of the participants (68.8\%) joined the programme because it is cheap and flexible. One male respondent had the following to say:

Obtaining a diploma in science education is a dream for everyone. My parents are poor such that they failed to meet fees [sic] for me to pursue further education. This programme is my last option because I will work at the same time [as] learning.

The desire to obtain a diploma that would enable the teacher to move to a better school also featured prominently (34.2\%). However, a minority of the preservice teachers (5.3\%) wanted the diploma in order to get access to leave the country.

By expressing that the programme is affordable, flexible, and allows them to obtain a diploma and move to a better school, the students manifested personal motivations. This notion concurs with findings by Azam (2001), whose research revealed that higher educational qualifications in remote districts offer students an opportunity for social mobility. Such qualifications would enable them to move to the more desired schools of the country.

\section{Problems Students Faced and Possible Solutions}

The shortage of reading materials during their studies, notably of textbooks, modules, and other reference books, as well as the shortage of library facilities, was identified as the major handicap by $68.4 \%$ of the preservice teachers. One student observed, "There is a problem of books. If you allow me to say SCRAMBLE for library books [sic] is a major problem." And another one complained of "inadequate learning materials (e.g., reference books, and no laboratory equipments for experiments).”

As the pioneers of the BUSE VODL programme, the students were confronted with a host of teething problems that impacted their learning experiences. These problems were both institutional and personal. For BUSE, which has traditionally offered conventional courses, ODL is a new adventure with its own idiosyncrasies and philosophy. Challenges encountered by the college include the provision of e-learning facilities and properly equipped libraries, among others. The provision of modules and handouts for sale in the library, more reference books, as well as improvements in laboratory facilities through mobile laboratories, were suggested by 54 of the participants $(71.1 \%)$ as possible solutions to this problem. Watson (2000) encourages institutions that provide ODL programmes to play a supportive and facilitative role in order to ensure that learners have access to quality library and information services to support their learning. In the case of BUSE, 10.5\% of the learners suggested that this could be achieved through the speedy introduction of virtual learning facilities at the learning centres. The nonavailability of enough ODL student support materials 
is a major weakness of the programme, especially because researchers in ODL programmes view these as crucial (Chikuya, 2007).

Although a shortage of learning materials was the major problem faced by the students, a sizeable proportion (52.6\%) identified financial problems as another obstacle affecting their studies. A small number (5.3\%) of the preservice teachers felt that some of the lecturers in the programme were incompetent and inexperienced. Galusha (1997) highlighted this possible pitfall and observed that in distance learning, students and teachers will find themselves playing different roles than is the norm in traditional education, hence they need to adapt to their new roles. In distance learning, the teacher is no longer the sole source of knowledge but a facilitator to support student learning, while the student actively participates in what and how knowledge is imparted. More than any other teaching methodology, distance learning requires a collaborative effort between student and teacher, unbounded by the traditional limits of time and single-instructor effort.

In order to alleviate the financial difficulties they face, $10.5 \%$ of the students urged the government to extend grants to fund their studies. The university is also encouraged by $53 \%$ of the students to consider ferrying them to the main campus for examinations or, better still, to conduct these examinations at the learning centres in order to reduce the costs incurred by the students in travelling to Bindura for examination sessions. Through these measures, it is hoped that a more conducive environment would be created for the students to undertake courses under open distance learning programmes.

\section{Students' Willingness to Undertake Further Studies under VODL}

Notwithstanding the above impediments, the majority of the participants endorsed the essence of the programme and hailed it as a noble initiative. Because of the competing priorities of work, home, and school, the structure of ODL programmes gives the student teachers a high degree of flexibility in that they have the greatest possible control over the time, place, and pace of their education (Galusha, 1997). In support of this assumption, the preservice teachers manifested a strong willingness to consider undertaking further educational courses through VODL programmes. Sixty-eight preservice teachers (89.5\%) said that they were willing to further their studies through a similar programme. Only $7.9 \%$ thought that studying under VODL was not an attractive option. Such a sentiment is summarised by the following student's comment: "No, because the course takes a lot of time to complete."

\section{Students' district of origin and their deployment preferences.}

A total of 76 participants took part in this study, [42 males (55.3\%) and 34 females (44.7\%)]. The majority of these participants (62, or $81.6 \%$ ) cited Mashonaland Central as their province of origin, and of these, $56(75.7 \%)$ come from Mbire and Guruve, which are the districts under study.

The majority of the preservice teachers (73.6\%) chose Mashonaland Central Province as 
their first-choice preference for deployment after graduation. Of these, $44.7 \%$ wanted to remain and teach in the rural areas of Mashonaland Central Province where the Mbire and Guruve districts are located. The results show a close relationship between area of origin and deployment desires, where the majority of those born in Mbire and Guruve wish to gain teacher certification and continue working in their district of origin. This is true for $62 \%$ of the respondents.

\section{Length of period taught in the district and students' deployment preferences.}

The majority of these preservice teachers (92.1\%) have been practising as relief teachers in the districts for two or more years. Those students who had been working in these districts for less than one year constitute $33 \%$ of those who prefer to continue teaching in these districts after graduation. Students who had spent between two and three years in Mbire and Guruve showed the highest preference (62.5\%) of continuing to teach in the districts. This is followed by those who had taught for more than three years. Of this group, $44 \%$ showed a willingness to teach in Mbire and Guruve. Cross-tabulated results manifest a relationship between the period of stay in the area and the deployment inclinations of the students, that is, the longer the period of stay in the districts (even for those who are not originally from Mbire and Guruve), the higher the preference by the students to remain and teach there after their teacher certification.

This result gives more credence to the presumption by Craig, Kraft, and du Plessis (1998) and UNESCO (2001) that these teachers may have family roots in these rural areas and are thus more willing to remain in these settings. However, the other $28.9 \%$ of the participants would want to teach in the urban areas of the same province. The urban schools of Mashonaland West and Harare attracted a combined $15.8 \%$ of the teachers' first-choice preferences.

As second choices, Mashonaland Central Province's urban areas were chosen by the highest total (23.7\%), while Mashonaland West urban (21.1\%) and Harare urban (10.5\%) occupied the second and third places respectively. A desire to move from this remote area to urban areas concurs with research findings made in Lesotho and Ghana, where recently qualified teachers preferred moving out of the rural postings to urban areas as quickly as possible (Rust \& Dalin, 1990; Azam, 2001).

As first- and second-choice preferences made by the teachers, Mashonaland Central rural province was the most popular choice, with $62.6 \%$. The provinces of Mashonaland East rural (18.4\%), Masvingo urban (10.4\%), and Harare urban (15.8\%) occupied the top three of the third- preference choices made by the preservice science teachers in the study.

None chose the same province as a third preference. The results manifest a strong preference by the preservice teachers to work in their home province but not necessarily in their home village or district. Such students may want to avoid the many demands made on them by family if they worked near their villages, as Mulkeen (2005) found out. This outcome 
opens a window of hope for the supply of teachers to rural schools in Africa.

\section{Conclusions and Recommendations}

Despite numerous difficulties encountered by the ODL preservice teachers in Mbire and Guruve districts, which included financial problems and a shortage of reading materials, the preservice teachers have shown a keen interest to train as science teachers. Motivations for enrolling in the training programme are both professional and personal. A study of the student motivators will help ODL institutions to develop appropriate course materials and techniques. While for many of the students, obtaining a diploma in science education equips them with the necessary content and methodology to be better science educators, others view the qualification as a chance for personal social mobility, which permits them to move to a better school or to teach in urban areas. The majority of the student teachers positively embrace the training programme and are willing to undertake further studies under the VODL programme. This is because of the advantages that are derived from obtaining an educational qualification through a flexible platform that allows them to work while learning at their "doorsteps" during school holidays.

In an endeavour to solve the problems faced in their studies, the students suggested several measures. They implored the government to look into the possibility of providing grants to finance their studies and also the Bindura University of Science Education to provide transport to ferry them to examination sessions, to provide better-equipped mobile libraries, and to introduce virtual learning facilities at the various learning centres. However, a close scrutiny of the intrinsic problems in distance education will help overcome some of the problems encountered by both the students and the institutions. There is also a need for research into course development techniques, which will enable institutions to identify the methods best suited to any ODL programmes they wish to undertake.

Targeted recruitment of relief teachers already working in the remote districts of Mbire and Guruve, done by BUSE, holds promise for their retention in that area after they graduate as qualified teachers. This study has shown that $92.1 \%$ of the preservice teachers had worked in the Mbire and Guruve districts as relief teachers for two or more years and that the majority (44.7\%) are willing to continue teaching in the same area after graduation. There is an assumption that during this period, many of them had established socioeconomic interests that would entice them to remain working in the district even after graduating as qualified science teachers (Craig, Kraft, \& du Plessis, 1998). This is a positive trend, especially in view of the fact that in many African countries rural areas have fewer qualified science teachers than urban areas due to poor working conditions. Centralised deployment of teachers has not been successful as teachers would still move out, especially science teachers, who are in great demand in the region as well as internationally, thereby fuelling brain drain (Chetsanga, 2000). It is, therefore, an encouraging signal that the ODL student teachers already working in these rural areas show a preference to continue teaching there even after graduation. Deliberate efforts should therefore be directed toward the recruitment of school leavers and relief teachers from disadvantaged rural areas who possess the requisite minimum 
entry qualifications to train as science teachers. 


\section{References}

Akyeampong, K., \& Lewin, K. (2002). From student teachers to newly qualified teachers in Ghana: Insights into becoming a teacher. International Journal of Educational Development, 22, 339-352.

Akyeampong, K., \& Stephens, D. (2002). Exploring the backgrounds and shaping of beginning student teachers in Ghana: Toward greater contextualisation of teacher education. International Journal of Educational Development, 22(3/4), 262-274.

Azam, J. P. (2001). The redistributive state and conflicts in Africa. Journal of Peace Research, 38(4), 429-444.

Black, T. R., Esanu, C., Mugambe, J., Namwadda, R., \& Walugembe, E. (1993). School improvement in the developing world: An evaluation of the Aga Khan Foundation programme. Retrieved from ERIC database. (ED 363930).

Cerda, C., Leon, M., \& Ropoll, M. (2001). Teachers learning to use information technology, Chile. In UNESCO (Ed.), Teacher education through distance learning pp. 11-12). Retrieved from http://unescodoc.unesco.org/images/o012/001242/124208e.pdf

Chetsanga, C. J. (2000). An analysis of the cause and effect of the brain drain in Zimbabwe. Harare: SIRDC. Retrieved from http://acpeu.euforic.org/civsoc/by_place/ zw.htm

Chikuya, H. H. (2007). Teacher education within the context of open and distance learning in Zimbabwe: A case study (Unpublished doctoral dissertation). University of South Africa.

Cohen, L., \& Manion, L. (1994). Research methods in education (4 ${ }^{\text {th }}$ Ed.). London: Routledge Falmer.

Craig, H. J., Kraft, R. J., \& du Plessis, J. (1998). Teacher development: Making an impact. Washington, D.C.:U.S. Agency for International Development.

Daniel, J. (2001). Preface. In UNESCO(Ed.)Teachereducationthrough distancelearning (p. iv). Retrieved from http://unescodoc.unesco.org/images/o012/001242/124208e. pdf

Ederinoye, R. (2001). An alternative route to primary teacher qualifications, Nigeria. In UNESCO (Ed.), Teacher education through distance learning (pp. 19- 20). Retrieved from http://unescodoc.unesco.org/images/o012/001242/124208e.pdf

Galusha, J. M. (1997). Barriers to learning in distance education. Interpersonal Computing and Technology, 5(3/4), 6-14.

Gottelmann-Duret, G., \& Hogan, J. (1998). The utilisation, deployment, and management 
of teachers in Botswana, Malawi, South Africa, and Uganda. Paris: UNESCO.

Hedges, J. (2000). The importance of posting in becoming a teacher in Ghana. University of Sussex Centre for International Education MUSTER Discussion Paper 13. Retrieved from http://www.sussex.ac.uk/usie/muster/reports/MDP\%2013-1102. doc

Hedges, J. (2002).The importance of posting and interaction with the education bureaucracy in becoming a teacher in Ghana. International Journal of Educational Development, 22, 353-366.

Mehrotra, R. N. (2001). Developing primary teachers' knowledge and skills in child guidance, India. In UNESCO (Ed.).Teacher education through distance learning (pp. 15-16). Retrieved from http://unescodoc.unesco.org/images/o012/001242/124208e.pdf

Mulkeen, A. (2005). Teachers for rural schools: A challenge for Africa. Paper presented at the Ministerial Seminar on Education for Rural People in Africa: Policy Lessons, Options, and Priorities. Addis Ababa: FAO, UNESCO, and the Association for the Development of Education in Africa.

Oliveira, J. B. (2001).Television-Plus: Journalism in the service of teacher development, Brazil. In UNESCO (Ed.), Teacher education through distance learning(pp. 7-8). Retrieved from http://unescodoc.unesco.org/images/o012/001242/124208e.pdf

Patton, M. (2002). Qualitative research and evaluation methods ( $3^{\text {rd }}$ ed.). Thousand Oaks, CA: Sage Publications.

Potter, C. (2001). New routes to teacher education degrees, South Africa. In UNESCO (Ed.), Teacher education through distance learning. (p. 23). Retrieved from http:// unescodoc.unesco.org/images/o012/001242/124208e.pdf

Robinson, B. (1997). Distance education for primary teacher training in developing countries. In J. Lynch,C. Modgil,\&S. Modgil (Eds.) Education and development: Tradition and Innovation, Volume 3: Innovations in delivering primary education. London: Cassell Educational Press.

Robinson, B., \& Latchem, B. (Eds).(2003). Teacher education through open and distance learning: World review of distance education and open learning, Volume 3. London: Routledge Falmer.

Rust, V., \& Dalin, P. (Eds.). (1990). Teachers and teaching in the developing world. New York: Garland.

Towse, P., Kent, D., Osaki, F., \& Kirua, N. (2002). Non-graduate teacher recruitment and retention: Some factors affecting teacher effectiveness in Tanzania. Teaching and Teacher Education 18, 637-652. 
UNESCO. (2000). The EFA 2000 assessment: Country reports, Zimbabwe. Retrieved from $\quad$ http://www.unesco.org/education/wef/countryreports/zimbabwe/rapport o.html

UNESCO. (2001). Teacher education through distance learning. Retrieved from http:// unescodoc.unesco.org/images/0012/001242/124208e.pdf

Walker, R. (2001). Using ICT to support school-based initial teacher education, UK. In UNESCO (Ed.), Teacher education through distance learning (pp. 25-27). Retrieved from http://unescodoc.unesco.org/images/o012/o01242/124208e.pdf

Watson, E. F. (2000). Library services to distance learners: The new professional paradigms. Retrieved from http://www.col.org/forum/pcfpapers/watson.pdf

Zhang,W.Y. \& Jian, N. (2001). Reaching teachers through television, China. In UNESCO (2001).Teacher education through distance learning (pp. 13-14). Retrieved from http://unescodoc.unesco.org/images/0012/001242/124208e.pdf

\section{Athabasca University $\mathbf{a}$}

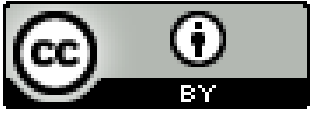

